UDC $124.5:$ [316.62 : 394]

TROITSKA OLENA,

Melitopol State Pedagogical University named after B. Khmelnytskyi (Melitopol, Ukraine)

e-mail: troizka2015@ukr.net, ORCID0000-0003-4330-084X

POPRAVKO OLGA,

Melitopol State Pedagogical University named after B. Khmelnytskyi (Melitopol, Ukraine)

e-mail: popravko_olga@ukr.net, ORCID0000-0002-4765-2300

SHCHERBAKOVANINA,

Department of Melitopol,

Tavria State Agrotechnological University named after Dmitryi Motornyi (Melitopol, Ukraine)

e-mail:rnk-07@ukr.net,.ORCID0000-0003-2632-2641

\title{
THE AXIOLOGICAL POTENTIAL OF THE HOLIDAY IN THE DEVELOPMENT OF THE COLLECTIVE MEMORY
}

The axiological potential of the holiday is uncovered in the article not as the form of the collective memory because of as the integral part of the culture which is appeared with the formation of the human society and it is accompanied it during all history. The holiday is not so the form as the content component of the culture which presents the values and the meanings of each epoch. At one time it forms the socio-cultural space, and it functions in it. This uninterrupted process provides the permanent actuality of the holiday for the society. Base upon on the heuristic potential of the cultural memory which is arisen as the uninterrupted process of the accumulation, the reproduction and the creation of the human knowledge about its cultural identity, the authors uncover the potentiality of the holiday as the cultural practice which does the functions of the cultural integration, the consolidation of the society and it is the way of the broadcasting, the presentation, the creation and the existence of the meaningful for the particular cultural community's meanings and the values. The reasons of the incomplete deployment of the axiological potential of the holiday in the social reality are analyzed and the conditions of the fixed holiday in the public consciousness are determined. It is proved the necessity of the providing of the historical and the cultural heredity of the traditions, "embedded" in the mechanism of the collective identification, the value-semantic communication, etc. Each new social formation tries to unite its members. For this purpose, the system of the historical mythologies is created which will establish the heredity and it will define the limits of the new society. As a result, the sacralization of the list of the holidays is occurred which begins to perceive as the integral element of the preservation of the collective identity. The fixing of the holiday is not only in the official calendar, but above all in the social consciousness, it will be possible only under conditions if it is provided the historical and the cultural heredity, which is supported by the traditions, in the other hand, the semantic content of the holiday will be lost. The holidays without support in the cultural memory do not get definition and cannot be considered as the holidays in the full measure of this concept, which includes not only the external design, the rituals, the ceremonies, the traditions of the celebration, and, above all, the reflexive and the emotional reproduction of the event as socially meaningful. The success of the beginnings and the preservation of each holidays are directly related to its "embedded" in the mechanism of the collective modern identification.

Key words: axiology; cultural identity; cultural memory; cultural practice; holiday.

\section{Introduction}

The theme of the memory is one of the most actual in the modern humanitarian research. Today it becomes the object of the study of sociology, of culturology, of philosophy of the culture, of the cultural anthropology and other spheres of the scientific knowledge, in which it is the important characteristic of the way of the life of the people; it defines its desire and the mood. The memory as the complex and the multicomponent phenomenon is the obligatory condition of the existence of the society which is based on the accumulation, the preservation and the translation of socially important information. This is a specially focused the consciousness which is reflected the special significance and the actuality of the information about the past 
and it is closely related to the present and the future. It is important to consider in the conditions of the modern "knowledge society" when, as Serhii Proleiev points out, "... in the conditions of the rapid change of the reality, the main experience of the man becomes the ability to respond to the unknown, the unexpected, and the unfamiliar. Finally, the ability to improvisation and the quick skillful reaction ... There is no need for the current situation of the general horizon, we need ad hoc, but not the meaning ... The horizon is folded in a locus ... It is important no understanding, but the adequacy and the efficiency of the done action. The understanding is posted the post-factum, which is after the event and it does not serve as its semantic precondition and the guide" (Proleev, 2014: 11-12).

About the actuality of the theme of the memory is evidenced the wide spector of the contexts, in which the researchers focus attention. In the modern scientific circulation, such concepts as "cultural memory", "social memory", "and historical memory" function. The comprehension of the memory in the culturological aspect focuses attention on the "cultural unity of the community", so it points to its collective character.

The holiday is an integral part of the culture. It appeared with the formation of the human society and it is accompanied its during all history. This is due to the scientific interest to the holiday, because it has always been in the field of the scientific research of the different branches of the humanitarian knowledge such as from ethnography to philosophy.

Each epoch has its own unique image, its set of the values and the norms, which is represented, in particular, in the holiday. After all, it at one time forms the socio-cultural space, and it functions in it. This uninterrupted process provides the permanent actuality of the holiday for the society.

In spite of the fact that the holiday is one of the most sustainable elements of the culture, the holiday calendar is constantly received certain changes such as some holidays disappear, and the new ones are replaced. This process is regular; it is due to the transformations that take place in the social life of the man (the change of the political regime, the social policy, the religion, etc.). However, as a rule, not all "new" holidays are recognized by the socium, many of them simply turn into just weekends or the opportunity to enjoy. In our opinion, the main reason of this "non-acceptance" is their disparity of the cultural memory of the celebration group. "To remember it means to revive the past in the memory, to make its part of the present, the part of the modernity" (Arnaiutova, 2003: 170). In this sense, what and in what way are mentioned, it becomes important. It actualized the need of the study and the use of the opportunities of the holiday as the form of the cultural memory.

The important place in the philosophical and cultural research belongs to the problem of the memory. Among the authoritative researchers who engages in the study of the cultural memory are J. Assman (2004), E. Berk (1979), O. Eksle (2003), J. Lotman (1992), M. Khalbvaks (2005) and others. We will notice that each of them focuses on the individual property of the cultural memory such as Yurii Lotman notices the culture as the collective memory in the context of the semiotic discourse; Mark Blok affirms that the cultural memory is shown up through micro-history ("life story") of the individual man; Paul Riker highlights the phenomenon of the human subjectivity: "the memory- obliviousness" as "anthropological structure of the historical condition".

Society-creating mission of the holiday, its symbolism, structural features and connection with the collective memory phenomenon is the subject of researches of Yu. Lotman (1992), E. Cassirer (2002), O. Maltseva (2012), C. Hassen (2001), N. Khrenov (2002) and others. In spite of presence of numerical bibliography, instrumental potential of the holiday as a way of consolidation of senses in the collective memory of a nation has not been disclosed rather thoroughly and consistently in present researches.

\section{The purpose of the study}

To determine the axiological potential of the holiday as the way of the reproduction, the integration and the creation of the new value-semantic construct of the cultural memory and the existential being.

The methodology of the research as the synthesized self-reflection of the historical humanist, first of all, in the research of the new knowledge should base on the human-centered approaches, the principles and the methods and also it should take into account the evolutional changes of the word society, the conceptual and the contextual influence on the consciousness of the man.

In the study used general scientific and specific culturological methods. The philosophical and methodological foundations of work were anthropological, axiological, dialogical, phenomenological approaches, and a world-wide interpretation of the well-known concepts of cultural memory; At the level of general scientific methodology methods of structural, functional analysis, theoretical reconstruction, content analysis and certain cognitive procedures (explication, reflection, etc.) were used. The process of understanding the memory as a phenomenon of culture involves the use of a cultural approach. To reveal the semantic load bearing the cultural memory, expressed in collective forms, the method of semiotic analysis was used; For comparing and interpreting cultural memory, the method of comparative analysis was used.

\section{Results and Discussion}

First, the term "cultural memory" was used by the German researcher Jan Assman for the denotation of the special type of the collective memory. He interprets the cultural memory as the complex, the multilayered phenomenon, as "special symbolic form of the transfer and the actualization of the cultural meanings which goes beyond the experience of the individual people or the groups." According to the scientist, the cultural memory is the uninterrupted process in which every social layer accumulates and reconstructs knowledge about oneself and its identity ... "The objective forms" of the cultural memory, or its "points of the fixation" are created with the help of the artistic, the graphic objects, the texts, the monumental constructions, as well as the rituals and the sacral action as the institutionalized forms of the communication, which are "figures of the memories... The bearers of the cultural memory are not necessarily contemporaries of "the actual union of those who remembers", and special (sometimes professional) saving and the bearers of the traditions, for example, the priests, the shamans, the bards, the teachers, the writers, the artists, 
the scientists". According to Assman, the new paradigm of the culture is around the memoirs about the past "in which the most diverse phenomena and the spheres of the culture such as the art and the literature, the politics and the society, the religion and the law appear in the new context" (Assman, 2004).

Considering that there are different definitions of the culture in the scientific literature, we notice that we were guided by the most accepted for our study the definition of the culture as the characteristic feature of the consciousness, the behavior and the human activity in the different situations.

The culture is historically, socially and personally determined the formation of the man to the nature, the society and himself, which determines the behavior and the actions of the man. However, as the French sociologist Mourice Khalbvaks notices that the memory of the individual man can only arise in the process of the socialization. Turning to the collective memory the man clarifies his memoirs, he fills up possible gaps and can even "borrow" other people's memoirs who forms in such way the idea of what he was not the direct witness. Khalbvaks writes that "there is the special artificial environment which is external to all individual consciousnesses, but the one that covers them; it is the kind of collective time and the space and the collective history. It is within such limits that there are thoughts (impressions) of the individuals, which leads to the fact that each of us stop to be ourselves. Soon we return to ourselves and bring in our consciousness from the outside the ready supporting points and the system units to which we tie our memoirs" (Khalbvaks, 2005). Khalbvaks affirms that the past is a social construction that it is built up in accordance with the spiritual needs of the present and it is a product of the cultural creation.

Jan Assman also speaks about the "reproducible" character of the cultural memory. The cultural memory, in his opinion, is formed with the way of the reproduction of the certain fragments of the past and their symbolic design: "The cultural memory is aimed at the fixed moments of the past. In it the past cannot be preserved as such. The past is more likely folded here in the symbolic figures to which the memories are joined" (Assman, 2004: 54).

Many modern researchers rightly notice that the individuality of the subjects is formed in the historical conditions. This history, which unites the representatives of one or another community, is the part of the collective past and it forms the basis of the group identity (G. Luibbe, L. Repina, J. Assman, etc.). It is regular that in such situation the cultural memory which covers the different forms of the address to the history, it acts as the collective past and it begins to do the unifying functions.

We notice that the collective memory does not always coincide with history. However, we do not forget that the past does not disappear without the trace; it keeps the connection with the modern. But, according to Fridrich Schelling, the only subject of the history is the only his (past) part which continues to exist in the present and it influences him.

The history as itself is not important for the cultural memory, but history is reproduced in memoirs and it is thus embodied in the myth and also it is the figure of the remembering. Jan Assman emphasizes that personalizing in the myth history does not become unrealistic, and on the contrary, only in such way it can become the reality in the sense of the constant normative and the formative force. Yurii Lotman observes that the culture is a collective intellect and the collective memory, that is, the individual mechanism of the preservation and the transmission of the certain messages (the texts) and the development of new ones. "In this sense, the space of the culture can be defined as the space of some common memory, that is, the space within some common texts can be preserved and it can be actualized. At the same time, their actualization takes place within the certain content invariant, which gives grounds to say that the text in the context of the new epoch saves, in some variant of the interpretation, the identity to itself" (Lotman, 1992: 200-202). The cultural memory establishes the main framework within the past becomes meaningful and the history becomes possible. At one time the cultural memory determines the events that will be fixed and those that will be remained without attention.

During all history "new" facts are constantly discovered, which have no real novelty, but they are given the meaning of the novelty and the significance. Yurii Lotman writes that "...the composition of the texts doesn't change as the texts themselves. Under the influence of the new codes which are used for the decryption of the texts which put aside in the memory of the culture in the past, the displacement of the meaningful and the insignificant elements of the structure of the text occur" (Lotman, 1992: 204). So, the cultural memory must be understood as one of the external measurement of the memory of the community which is responded for the transfer of the sense in the culture, and through the address to the past, it is grounded the cultural identity of the community which is mentioned.

The cultural memory is called to determine the affiliation of the individual to the particular community, to correlate its individual memoirs with the memory of other representatives of this society. We notice that the cultural memory of some society is supported "not only with sacral texts ... but with the cultural practices that make it possible to actualize the distant past in the form of the certain ritual" (Assman, 2004: 213-217). The first forms of the cultural memory were the myth and the ritual which is conduced to the transfer of the collective knowledge to the next generations, their codification and the fixation. The mythological complex was the main way of the preservation and the representation of the cultural memory in the traditional societies. In modern society, the myth and the ritual show themselves in the holiday as the symbolic form of the culture. It gives grounds to consider the holiday as the certain cultural practice which will promote the preservation and the representation of the collective memory.

The holiday is the fundamental and the integral element of the cultural existence of the man which does not belong to the certain synchronous cut of the culture, but it penetrates its through which is stated its anthropo-social measurement. In the social history of the man who begins with its origins, the holiday was the universal form of the emotional and the symbolic expression, the affirmation and the translation of the most important values-ideological settings of the culture in its specific socio-historical form. It gives grounds to comprehend it as the specific, "nongenetic" memory of the people collective. It is generally acknowledged that the presence of the general, the collective memory is the most important condition of the existence of some society.

The holiday as one of the cultural practices plays the important function of the cultural integration of the society 
which accepts or it does not accept the holiday. The cultural memory directly correlates with the social groups; it always oriented to the modern situation, which makes it actual. The texts and the rituals fix the cultural memory, and with the help of the special bearers, it is interpreted, it is saved and it is institutionalized. It "has the value, the relevance and the reflexivity, because of the interpretation of the cultural memory and the embodiment of it in the practice help the social group to form its image, its own idea of the past" (Eksle, 2003: 39) which is fixed in the appropriate traditions, and the holiday is the bearer of these traditions and the time of their reproduction.

The holiday as the especial action which was excluded from the everyday life; it was given the sacral meanings, which was provided its connection with the "axial" time. As Mirche Eliade notices "the holiday appears as the actualization of the beginning of the universe, Urzeit, the initial epoch of the creation, when all things, the living beings, the social institutions have developed in their traditional and the final form" (Eliade, 2010: 23). Such address to eternal values gives the possibility to the society to rejuvenate, to withstand time, and to conduct the parallels with the modernity.

Today, this function of the holiday is quite controversial. The results of the researches show that the limit between the holiday and the everyday life is washed away; it stops to be the unique event which is turned into the simulacrum of the "game on the holiday" which is mainly imposed on the society. The modern holiday has lost clearly determined spatial-temporal limits which are dissolved in the so-called "holiday events" which are replicated with the means of the mass media for the consumer society. At the same time, the holiday becomes a single event, which does not send for something and does not have the continuation in the future, or on the contrary it goes on without valid reason on that.

One of the ontological essences of the holiday is that it unites the different groups. The affiliation to the particular community is the important need of every people. Abraham Maslow is the author of the famous "pyramid" of the human needs, located it in the third place after the needs of the physiological level and the level of the safety. The holiday has always been the special event and the means of the consolidation of the particular group. If the daily culture is "axifugal" in its essence, as it "divides" the integrality of the society on the different features (professional, gender, age, etc.) so, the holiday culture, on the contrary, plays the important function of the integration and the consolidation of the society. At the same time, it is as the channel of the broadcasting and the exchange of the values and the meanings which are significant for the given cultural community and in actual and in the continual contexts. The Polish professor Elzhbeta Matinia writes: "In society sometimes there is the protest, as well as the struggle with previously prepared and the imposed forms of the behavior; these protests can be compared with the carnival with embedded in its temporarily sanctioned disagreement. This unstable sphere of the community and the dialogue play the significant role in the appearance of the network of the civil positions and the revival of the embryonic public sphere" (Belov, 2015: 559-567).

The basis of the holiday consolidation is the felling of the affiliation and the empathy which are arisen in the process of the ritual design of the important event for the society. The holiday gives the opportunity to feel involved with it, to worry and to manifest their consent with the event and its mark, and also to keep the memory of this event for all representatives of the cultural community including the sub-cultural formations, which is the important for the preservation of the integrity of the community and it comes out the limits of the everyday life.

The holiday is a sphere of the personalized, the common meanings, which people preserve, reproduce and transmit from the generation to the generation in the special way. In this quality, it does not only constitute the sociality of the man, but also its individuality. By the definition of Edmund Berk the holiday is the system of the social symbols and the meanings, where "self", the emotional sphere and the subjective experience are formed (Berk, 1979: 168).

The regular cyclical "repetition" in the holiday rituals, in which symbolically the most significant for the certain community the highest values and meanings are embodied and fixed, and also the productive experience of the socio-cultural life which is given the holiday the functional significance of the collective memory and the mechanism of the cultural heredity.

The collective experience does not broadcast directly in the culture. It is generalized, it is reflected, it is comprehended and it is transmitted to the next generations with the help of the symbolic "language" of the culture through the complex of its symbolic forms. In this sense, in fact, the holiday and especially its special ritualspectacular language is a symbolic expression of once established examples or the types of the behavior which is led to automatism their constant ritual-cyclic repetition. In such way, it becomes the reservoir of the collective memory and the important part of the mechanism of the imitation of the traditions with the help of which the social life looks for the additional support of its stability. With the help of the holiday the traditional experience is reproduced again and again and in this way it is transmitted in the time from the generation to the generation.

In turn, doing these functions the holiday gives the cultural reality the determined ethnic and the national specificity. As the comparative analysis of the holidays of the different nations is shown some holiday's elements have the general character and can be repeated in the traditions of many peoples. First of all, this concerns the layer of the holiday which is symbolically expressed the sacral meanings. But these elements are inscribed in the general system of the traditions and can form the new combinations with other elements which are symbolically expressed the generalized collective experience, which is significant for the particular cultural community. In this particular systematic interconnection lies down the source of the individual uniqueness of the cultures and the broadcasting of the experience of each of them. This particular systematic interconnection gives the holiday the character of the original and the unique holiday culture of the certain peoples. Within this holiday culture the holiday can be transformed from the certain ideal-typical construct to the real phenomenon of the cultural existence. And in this quality it strengthens, it takes root and it transfers the traditional values of this particular culture, defining its ethnic and the national specificity.

The functional ability of the holiday determines the ethnic and the national specificity of the culture and also it occupies one of the leading places among the cultural mechanisms of the formation of the national character. 
The representatives of the School of "Annaliv" (R. Benedikt, M. Mid, D. Rissman, V. Ovchinnikov, etc.) working on the development of the concept of the "national character" aim to catch the special spirit of the culture; who studies the way of the life, the everyday life, the norms of the communication, the religion, the traditions of the different peoples. The scientists have revealed that the basis of the national character is the stable frequency of the stereotypes of the man's behavior which is realized, first of all, in the interpersonal interaction. Regularly cyclically repeating holiday rituals with their specific communicative codes actualize and organize this type of the interaction creating the sturdy basics for the formation of the national character.

\section{Conclusions}

During all history of the humanity the holiday was the universal form of the emotional and the symbolic expression, the affirmation and the broadcasting of the most important values-worldview settings of the culture in its concrete historical form. The holiday culture is the sphere of the personalized, the general meanings which are preserved and reproduced by the members of the society and, in the special way, they are transmitted from the generation to the generation. In this quality it fixes the sociality of the man and the integrity of the society.

Each new social formation tries to unite its members. For this purpose, the system of historical mythologies is created which will establish the heredity and define the limits of the new society. As a result, the sacralization of the list of the holidays is taken place which can be perceived as the integral element of the preservation of the collective identity. At the same time, it should be remembered that the creation of the new version of the cultural memory and its fixing with the help of the holiday are always taken place gradually. However, the fixing of the holiday is not only in the official calendar, but first of all in the social consciousness; it will be possible only on the conditions if it is provided with the historical and the cultural heredity, which is supported with the traditions, in the other hand, the semantic filling of the holiday is lost. The holidays without support in the cultural memory do not receive the recognition and cannot be considered as the holidays in the full measure of this concept, which is not included the external design, the rituals, the ceremonies, the traditions of the celebration, bur, first of all, the reflexive and the emotional reproduction of the event as socially meaningful. The success of the beginning and the preservation of each holiday are directly related to its "embedded" in the mechanism of the collective identification.

\section{REFERENCES}

Arnaiutova, Y. E. (2003). From memoria to "memory history". In Gurevich, A. Y. (ed.). Odyssey. Man in history. Moscow: Nauka, pp. 170-198. (In Russian).

Assman, Y. (2004). Cultural memory: letter, memory of the past, and political identity in the high cultures of antiquity (Trans. from German by M. M. Sokolskaya). Moscow: Languages of Russian Culture, 363 p. (In Russian).

Belov, I. (Ed.) (2015). Dialogue Guide. (Trans. by D. Wiren, A. Davtyan, V. Okun). Seini: Fond "Pogranichije", 590 p. (In Russian).

Berk, E. (1979). Philosophical study of the origin of our ideas of sublime and beautiful. (Trans. from English by B.V. Meerovskii). Moscow: Progress, 237 p. (In Russian).
Cassirer, E. (2002). The philosophy of symbolic forms. Mythological thinking: in $2 \mathrm{vol}$. Vol. 2. M.; SPb.: University book, 280 p. (in Russian)

Eksle, O. G. (2003). Aristocracy, memoria and cultural memory. The images of the past and the collective identity in Europe before the beginning of the New Age. M.: Krug, pp. 38-51. (In Russian).

Eliade, M. (2010). Aspects of the myth. Trans. from French by V.P. Bolshakova. M.: Academic Avenue, 256 p. (In Russian).

Hassen, S. (2001). Exemption from the psychology of violence. SPb.: Prime-Eurovision, 400 p. (In Russian).

Khalbvaks, M. (2005). Collective and historical memory. Inviolable reserve, № $2 / 3$ (40/41). Retrieved from http:// magazines.russ.ru/nz/2005/2/ (In Russian).

Khrenov, N. A. (2002). Culture in the era of social chaos. M.: Editorial URSS, $448 \mathrm{p}$

Lotman, Y. M. (1992). Memory in cultural lighting. Selected articles: in 3 vol. Vol.1. Tallinn: Alexandra, 478 p. (In Russian).

Maltseva, O. (2012). Assimilation of the holiday and festive laughter in the broader routine: the causes, mechanisms and consequences of the phenomenon. Skhid, 4 (118), pp. 144-149. Retrieved from http://skhid.kubg.edu.ua/article/view/16574 (in Ukrainian).

Proleev, S. V. (2014). "Society of knowledge" as an anthropological situation. Philosophy of Education, №1 (14), pp. 7-24. (In Ukrainian).

\section{LIST OF REFERENCE LINKS}

Арнаутова Ю. Е. От memoria к "истории памяти". Одиссей. Человек в истории / А. Я. Гуревич (ред.). М.: Наука, 2003. C. $170-198$.

Ассман Я. Культурная память: письмо, память о прошлом и политическая идентичность в высоких культурах древности / пер. с нем. М. М. Сокольской. М.: Языки русской культуры, 2004. 363 с.

Берк Э. Философрское исследование о происхождении наших идей возвышенного и прекрасного / пер. с англ. Б. В. Мееровский. М.: Прогресс, 1979. 237 с.

Кассирер Э. Философия символических форм. Мифологическое мышление: в 2-х томах. Том 2. М.; СПб.: Университетская книга, 2002. 280 с.

Лотман Ю. М. Память в культурологическом освещении. Избранные статьи: в 3-х т. Т. 1. Статьи по семиотике и топологии культуры. Таллин: Александра, 1992. 478 с.

Мальцева О. Асиміляція свята і святкового сміху в обширах буденності: причини, механізми та наслідки феномена. Cxid, 2012, № 4 (118), 144-149. URL: http://skhid.kubg.edu.ua/ article/view/16574

Пролеєв С. В. "Суспільство знань" як антропологічна ситуація. Філософрія освіти. 2014. № 1 (14). С. 7-24.

Руководство по диалогу / гл. ред. Белов И.; пер. Д. Вирен, А. Давтян, В. Окунь. Сейны: Фонд "Пограничье", 2015. 590 с. Хальбвакс М. Коллективная и историческая память. Неприкосновенный запас. 2005. № 2/3 (40/41). URL: http:// magazines.russ.ru/nz/2005/2/.

Хассен С. Освобождение от психологии насилия. СПб.: Прайм-ЕВРОЗНАК, 2001. 400 c.

Хренов Н. А. Культура в эпоху социального хаоса. М.: Едиториал УРСС, 2002. 448 c.

Эксле О. Г. Аристократия, memoria и культурная память. Образы прошлого и коллективная идентичность в Европе до начала Нового времени. М.: Кругъ, 2003. С. 38-51.

Элиаде М. Аспекты мифра / пер. с фр. В. П. Большакова. М.: Академический проспект, 2010. 256 с. 
Троїцька Олена,

Мелітопольський державний педагогічний університет

імені Богдана Хмельницького (Мелітополь, Україна)

e-mail: troizka2015@ukr.net, ORCID0000-0003-4330-084X

\section{Поправко Ольга,}

Мелітопольський державний педагогічний університет

імені Богдана Хмельницького (Мелітополь, Украӥна)

e-mail: popravko_olga@ukr.net, ORCID 0000-0002-4765-2300

Щербакова Ніна,

Мелітопольське відділення Таврійського державного агротехнологічного університету

імені Дмитра Моторного (Мелітополь, Украӥна)

e-mail:rnk-07@ukr.net, ORCID0000-0003-2632-2641

\section{АКСІОЛОГІЧНИЙ ПОТЕНЦІАЛ СВЯТА У РОЗВИТКУ КОЛЕКТИВНОїПАМ'ЯТІ}

У статті розкрито аксіологічний потенціал свята та його роль у розвитку культурної пам'яті. Спираючись на аналіз евристичного потенціалу культурної пам'яті, що постає неперервним процесом акумуляції, відтворення і створення знання людини про свою культурну ідентичність, автори експлікують потенційність свята не стільки як форми культурної пам'яті, скільки як культурної практики, що спирається на канони постмодернізму, а саме на постметафізичне мислення, на відмову від логоцентризму, на лінгвістичний і комунікативно-діалогічний поворот у розумінні свята як способу інтеграції та консолідації суспільства. Обґрунтована роль свята як конструкта трансляції, презентації і творення значущих для певної культурної спільноти у часі й просторі смислів і цінностей культурного буття людини. Проаналізовано причини неповного розгортання аксіологічного потенціалу свята у соціальній дійсності, що пов'язані насамперед 3 пануючим розумінням свята у межах презумпції єдиної системно-концептуальної моделі, яка не враховує дискурсивні, екзистенціально-інформативні (діалогічні) смисли-цінності, а також не спирається на сучасні феномени пріоритету простору (тут і тепер) на противагу часовому виміру з яким пов'язана пам'ять. Визначено умови закріплення свята у суспільній свідомості. Доведена необхідність забезпечення історичної й культурної спадковості через "вбудованість" у механізм колективної ідентифікації ціннісно-смислового потенціалу спілкування. Експлікована роль свята як конструкту реалізації людиною власного життєвого світу й діалогічності натхнення.

Ключові слова: аксіологія; культурна ідентичність; культурна пам'ять; культурна практика; свято.

(c) Troitska Olena, Popravko Olga, Shcherbakova Nina

Надійшла до редакції: 20.05.2019

Прийнята до друку: 11.06.2019 